\title{
MINIREVIEW
}

\section{Characteristics and functions of human cytomegalovirus UL128 gene/protein}

\author{
R. TAO, J. XU, H.-H. GAO, W.-T. ZHAO, S.-Q. SHANG* \\ Children's Hospital, Zhejiang University School of Medicine, Zhejiang Key Laboratory for Diagnosis and Therapy of Neonatal \\ Diseases, 57 Zhugan Lane, Yan'an Road, Hangzhou 310003, P. R. China
}

Received September 25, 2013; accepted April 25, 2014

\begin{abstract}
Summary. - Human cytomegalovirus (HCMV) ORF UL128 protein is highly conserved among viral field isolates and functions in two different molecular forms, monomeric UL128 protein and in a complex with glycoproteins $\mathrm{gH}, \mathrm{gL}, \mathrm{UL130}$, and UL131A protein. Monomeric UL128 protein works as soluble chemokine analogue to attract peripheral blood mononuclear cells (PBMCs) and selectively induces expression of interleukin 6 (IL-6) and tumor necrosis factor $\alpha$ (TNF- $\alpha$ ) in PBMCs. The gH/gL/UL128/UL130/UL131A complex is indispensable for entry into both endothelial and epithelial cells. In conclusion, UL128 plays an important role in HCMV infection.
\end{abstract}

Keywords: human cytomegalovirus; UL128 gene/protein; chemokine

\section{Contents:}

1. Introduction

2. Characteristics of UL128 gene and protein

2.1 UL128 gene

2.2 UL128 protein

3. Role of UL128 protein in HCMV infection

3.1 Functions of monomeric UL128 protein

3.2 Functions of complexed UL128 protein

4. Conclusions

\section{Introduction}

HCMV is a widespread herpesvirus, and the seroprevalence in people varies from $45 \%$ to $100 \%$ (Cannon et al., 2010). After the primary infection, it usually persists for the whole life of an individual in a latent form. Although HCMV does not cause severe diseases in immunocompetent people,

*Corresponding author. E-mail: rtao1211@aliyun.com; phone: +86-571-88873446.

Abbreviations: $\mathrm{EnC}(\mathrm{s})=$ endothelial cell $(\mathrm{s}) ; \mathrm{EpC}(\mathrm{s})=$ epithelial cell(s); ERK = extracellular regulated protein kinase; $\mathrm{gB}=$ glycoprotein $\mathrm{B} ; \mathrm{gH}=$ glycoprotein $\mathrm{H} ; \mathrm{gL}=$ glycoprotein $\mathrm{L} ; \mathrm{HCMV}=$ human cytomegalovirus; IL-6 = interleukin 6; MAPK = mitogen-activated protein kinase; $\mathrm{PBMC}(\mathrm{s})=$ peripheral blood mononuclear cell(s); $\mathrm{RCMV}=$ rat cytomegalovirus; TNF- $\alpha=$ tumor necrosis factor $\alpha$ congenital infection is the leading viral cause of defects at birth, including wide range of neurodevelopmental disabilities and hearing loss. In immunocompromised patients with AIDS and after allogeneic bone marrow or organ transplants, HCMV infections often lead to life-threatening diseases (Vanarsdall et al., 2008).

HCMV usually establishes primary infection in two ways. The first is via epithelial cells (EpCs) of the rhinopharynx or the genital tract if the route of transmission is oral or sexual contact. The second way is via endothelial cells (EnCs) of the vascular tree, if the route of transmission is blood transfusion. PBMCs are also important sites for HCMV infection. They are recruited at the sites of primary infection, carrying virus and viral products, thus initiating haematogenous dissemination and contribute to the reactivation by cell differentiation (Reeves and Sinclair, 2008). During this process, HCMV expresses a number of proteins to achieve cell tropism, transmission, reactivation, and immune evasion (Revello and Gerna, 2010; Avdic et al., 2011; Montag et al., 2011).

Recent studies have revealed that the product of HCMV ORF UL128 can interact with many different cell types including EnCs, EpCs, and PBMCs. It may play a part in virus infection through the interference with these cells. In this review, we describe the current knowledge about the characteristics of the UL128 gene and protein and func- 
tions of two different forms of the protein, monomeric and bound to the $\mathrm{gH} / \mathrm{gL} / \mathrm{UL} 130 / \mathrm{UL} 131 \mathrm{~A}$ complex, in infection of different cell types.

\section{Characteristics of UL128 gene and protein}

\subsection{UL128 gene}

UL128 gene is found to be highly conserved among 34 wild virus isolates in pregnant women with primary HCMV infection, their fetuses or newborns, as well as in solid organ transplant recipients and patients with AIDS (Baldanti et al., 2006). However, it exhibits high variation between different strains: the Merlin strain has a $\mathrm{C}$ to $\mathrm{T}$ transition in UL128 exon 3, which introduces a stop codon and leads to premature translational termination; the 3157 strain has a $\mathrm{G}$ to $\mathrm{C}$ transversion in the GT dinucleotide of the splice donor site at the end of UL128 exon 1 which disrupts splicing; the Toledo strain has an inversion of a substantial region, which results in disruption of UL128 by introducing UL148A in place of UL128 exon 3 (Dolan et al., 2004). In addition, UL128 gene is demonstrated to be suppressed when HCMV strains are extensively passaged in human fibroblasts (Dolan et al., 2004; Dargan et al., 2010). These strains also loose their ability to grow in epithelial and endothelial cells, indicating that UL128 gene may play an important role in HCMV infection.

Sequencing of clinical strains showed that UL128 gene has two sets of transcription patterns, one consisted of three 519 nt long exons, and the other consisted of three exons with the first $642 \mathrm{nt}$ long intron (Sun et al., 2010). The respective roles of two patterns of UL128 transcript in HCMV infection still requires further exploration.

\subsection{UL128 protein}

UL128 proteins of the HCMV, chimpanzee cytomegalovirus (CCMV) and simian cytomegalovirus (SCMV) commence with a predicted signal peptide, suggesting they may be secreted and work as a soluble molecule. Moreover, UL128 proteins share four conserved cysteine residues near their $\mathrm{N}$ termini which is the structural characteristic of $\beta$ - (or CC-) chemokines (Akter et al., 2003). These findings indicate that monomeric UL128 protein may be secreted and may act as a $\beta$-chemokine analogue in HCMV infection, just as HCMV ORF UL146 encoding a homologue of $\alpha$-chemokine vCXC-1 (Penfold et al., 1999).

UL128 protein was also proved to act as a part of the $\mathrm{gH} / \mathrm{gL} / \mathrm{UL} 128 / \mathrm{UL} 130 / \mathrm{UL131A}$ complex in the process of entry into EnCs and EpCs (Hahn et al., 2004; Ryckman et al., 2008a; Ryckman et al., 2006; Wang and Shenk, 2005). The protein-protein interactions in $\mathrm{gH} / \mathrm{gL} / \mathrm{UL} 128 / \mathrm{UL} 130 /$ UL131A complex are confirmed to operate as follows: $\mathrm{gH}$

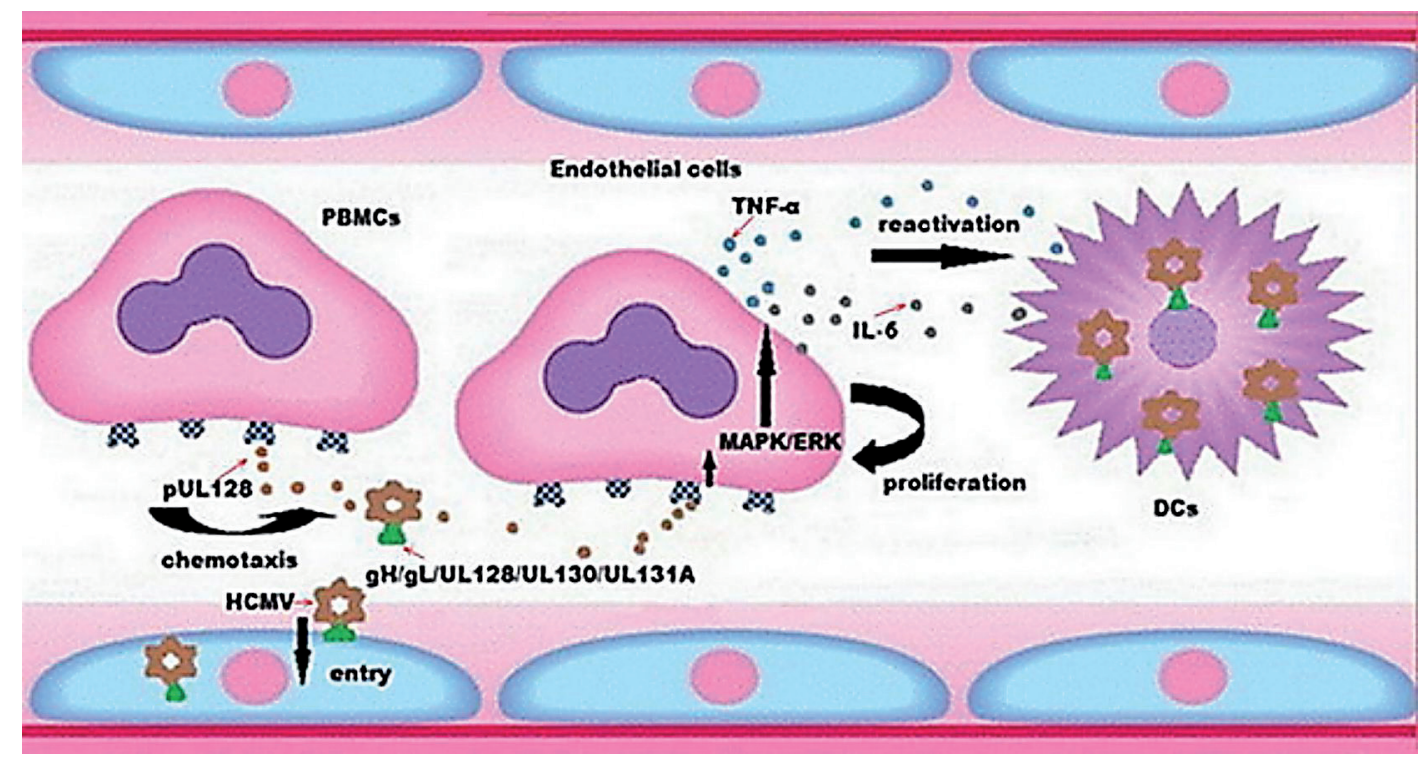

Fig. 1

Functions of UL128 protein

The figure illustrates the main functions of UL128 protein. Monomeric pUL128 protein attracts PBMCs to infected area, promotes PBMCs to proliferate by activating the MAPK/ERK signaling pathway, induces IL- 6 and TNF- $\alpha$ expression in PBMCs and contributes to reactivation of HCMV. The complexed UL128 is indispensable for HCMV entry into EnCs and EpCs. 
protein together with gL and also UL130 with UL131 interact through disulfide linkage; UL128 interacts with both UL130 and gL through noncovalent interactions and a surface created by both $\mathrm{gH}$ and $\mathrm{gL}$ is required for UL131 binding. The whole pentamer is predicted to be inserted in to the virion envelope through gH (Ryckman et al., 2008b).

Since UL128 protein has two kinds of molecular forms in HCMV infection, it may work in different ways to contribute to the pathogenesis of the virus.

\section{Role of UL128 protein in HCMV infection}

In vivo, HCMV can infect a broad range of cell types including fibroblasts, EnCs, EpCs, monocytes, macrophages, and smooth muscle cells (Scrivano et al., 2011). Two molecular forms of UL128 protein, namely monomeric UL128 protein and complexed UL128 protein, act by different ways to influence various cells involved in HCMV infection.

\subsection{Functions of monomeric UL128 protein}

There are several reports on the relationship between monomeric UL128 protein and PBMCs. For example, monocytes as an important part of PBMCs have been described as shelters for HCMV to avoid clearance, vehicles for HCMV dissemination and reservoirs for HCMV latency (Frascaroli et al., 2006; Chan et al., 2012; McCormick et al., 2010). Monocytes originating from CD $34^{+}$progenitors in the bone marrow circulate in the bloodstream for 1 to 3 days and then move into peripheral tissues to differentiate toward macrophages and dendritic cells. They will encounter HCMV in the bone marrow, the bloodstream, and the peripheral tissues during or after transendothelial migration from the bloodstream (Straschewski et al., 2011). Monocyte movements are tightly controlled by members of chemokines and their receptors to ensure the movements occur in the proper spatial and temporal fashion during immune responses (Lira and Furtado, 2012).

Since UL128 protein may be secreted and works as soluble chemokine analogue, we have synthesized recombinant UL128 protein and proved it could attract PBMCs with potency equal to that of MIP- $1 \alpha$ in vitro by chemotaxis assay (Gao et al., 2012). This result is in line with the previous study that the 129 protein encoded by rat cytomegalovirus (RCMV) also as a CC chemokine analogue was demonstrated to be released into culture supernatants of RCMV infected cells and induced migration of lymphocytes isolated from rat (Vomaske et al., 2012). In our previous report, UL128 protein was also proved to promote PBMCs proliferation by activating the MAPK/ERK signaling pathway (Zheng et al., 2012). On the contrary, Straschewski et al. (2011) demonstrated that soluble recombinant UL128 protein could block chemokine-driven migration of monocytes by down-regulation of CCR1, CCR2, and CCR 5 chemokine receptors. The possible reason for the controversy may be that monomeric UL128 protein interacts with more chemokine receptors than CCR1, CCR2, and CCR5 to influence the migration of monocytes. That means, UL128 may work as a viral protein to interfere with chemokine-driven motility or as a $\beta$-chemokine homologue to attract monocytes depending on the chemokine receptors it recognizes. In the case of UL128 impairing chemotaxis of monocytes towards inflammatory chemokines CCL2 and CCL 5 by down-regulation of chemokine receptors CCR1, CCR2, and CCR5 (Straschewski et al., 2011), it indicates that strict chemokine-dependent directional controls are absent in these monocytes, and the immune response of the host may be paralyzed. On the other hand, it is possible that UL128 docks the virions to a specific chemokine receptor of monocytes, such as CCR8 (Tiffany et al., 1997), activating the MAPK/ERK signaling pathway to promote proliferation of monocytes, recruiting uninfected monocytes to the infected tissue, and eventually increasing viral targets and promoting viral spread. In brief, UL128 protein would be able to facilitate HCMV infection by hindering host immunity or promoting viral transmission based on its bidirectional regulation of chemokine motility.

In addition, we demonstrated that UL128 protein could selectively induce cytokine expression in PBMCs, such as IL- 6 and TNF- $\alpha$, which are involved in HCMV reactivation and virus spread (Zheng et al., 2012). The increased serum levels of TNF- $\alpha$ in the patients with sepsis and atopic dermatitis were related to the activation of latent HCMV (Kutza et al., 1998; Docke et al., 2003). Expression of IL-6 was involved in dendritic cells differentiation to influence HCMV reactivation (Huang et al., 2012; Reeves and Compton, 2011). Moreover, IL-6 and granulocyte-macrophage colonystimulating factor (GM-CSF) are related to HCMV-mediated angiogenesis, which contributes to virus spread and the development of HCMV-associated vascular diseases (Botto et al., 2011; Fiorentini et al., 2011). These findings suggest that monomeric UL128 protein may interfere with certain inflammatory cytokines to increase HCMV replication and dissemination.

\subsection{Functions of complexed UL128 protein}

HCMV replication in EnCs and EpCs appears to be important in virus persistence and spread. EnCs and EpCs are the primary targets for HCMV infection in immunocompromised patients (Revello and Gerna, 2010). Some EnCs originating from $\mathrm{CD} 34^{+}$stem cells act as the reservoirs of HCMV in the host and also the sites of virus latency (Quirici et al., 2001; Cheung et al., 2006). Microvascular EnCs of 
capillaries and venules in various organs, including the entire gastrointestinal tract, lungs, kidneys, liver, salivary glands and brain are susceptible to HCMV, indicating that HCMV-infected EnCs contribute heavily to dissemination of HCMV infection (Revello and Gerna, 2010; Bissinger, et al., 2002). EpCs are also the cell type that is mostly involved in HCMV infection in vivo, and are predominantly infected cell population in the gastrointestinal tract, secretory glands and kidneys (Sinzger et al., 2008).

The previous researchers have opened the door to the discovery of UL128 protein as an important part of $\mathrm{gH} / \mathrm{gL} /$ UL128/UL130/UL131A complex. The complex has been characterized as structural component of the viral envelop (Ryckman et al., 2008a; Wang and Shenk, 2005; Adler et al., 2006; Patrone et al., 2005), which is indispensable for infecting both EnCs and EpCs (Hahn et al., 2004; Ryckman et al., 2006, 2008a; Wang and Shenk, 2005). The significance of $\mathrm{gH} / \mathrm{gL} / \mathrm{UL128/UL130/UL131A} \mathrm{complex} \mathrm{in} \mathrm{viral} \mathrm{entry}$ is based on several facts. Firstly, HCMV entry into EnCs depending on particular strains suggests that specific viral genes are required for efficient replication in this cell type. HCMV strains which were extensively passaged in human fibroblasts such as AD169 lose their ability to grow in EnCs and EpCs (Grazia et al., 2001). The HCMV strains extensively passaged in fibroblasts could gain loss-function mutations of UL128, UL131A or UL130 (Spear and Longnecker, 2003). Secondly, recent experiments demonstrated that antibodies against pUL128, pUL130 or pUL131A potently neutralize the entry into EnCs and EpCs but have no effect on fibroblasts (Wang and Shenk, 2005; Adler et al., 2006; Gerna et al., 2008; Macagno et al., 2010). Thirdly, introduction of targeted deletions into the UL128/UL130/UL131A locus affects the ability of HCMV growing in EnCs or transmitting to leukocytes, and gain of function is associated with reversal of mutations within UL128/UL130/UL131A or trans-complementation with individual UL131A, UL130 or UL128 genes by retrovirus-mediated transduction (Hahn et al., 2004).

The definite mechanism of gH/gL/UL128/UL130/ UL131A complex participating in the cellular tropism of HCMV is poorly understood. Ryckman et al. indicated that $\mathrm{gH} / \mathrm{gL} / \mathrm{UL} 128 / \mathrm{UL} 130 / \mathrm{UL} 131 \mathrm{~A}$ complex contributed to HCMV adsorption, penetration, and entry to EnCs and EpCs by endocytosis and the process was dependent on low pH (Ryckman et al., 2006). Once HCMV entry was initiated, gH/gL/UL128/UL130/UL131A complex would attach to a certain receptor involved in HCMV entry or signaling transduction (Ryckman et al., 2008a). This receptor contributed to gB transition from a protease-resistant to proteasesensitive form so that $\mathrm{gB}$ could interact with $\mathrm{gH}$ (Patrone et al., 2007). Glycoprotein homologues, gB, gH, and gL were essential for cell fusion and the interaction between $\mathrm{gB}$ and $\mathrm{gH} / \mathrm{gL}$ were sufficient for HCMV fusion execution (Vanars- dall et al., 2008; Gerna et al., 2008; Patrone et al., 2007). The above hypothesis is in line with the process of HCMV entry into fibroblast cells, which promotes a transient association between the $\mathrm{gB}$ receptor as epidermal growth factor receptor and the $\mathrm{gB} / \mathrm{gH}$ receptor integrin $\alpha \mathrm{V} 3$ (Wang et al., 2005). But up to now, the detailed roles of UL128, UL130 and UL131A in the pentamer, and which of the proteins is most important, still remains unknown and requires further research. For example, UL131A had been proved to be important in virus entry into EnCs, however, it could not eliminate the possibility that UL128 protein played a more crucial role in virus entry (Adler et al., 2006).

\section{Conclusions}

HCMV ORF UL128 gene is highly conserved among viral field isolates and has two different molecular forms, monomeric UL128 protein and complexed UL128 protein as a part of $\mathrm{gH} / \mathrm{gL} / \mathrm{UL128} / \mathrm{UL} 130 / \mathrm{UL} 131 \mathrm{~A}$ complex. Monomeric UL128 protein is produced and works as a soluble chemokine analogue to attract PBMCs and selectively induces expression of IL- 6 and TNF- $\alpha$ in PBMCs. The gH/ $\mathrm{gL/UL128/UL130/UL131A} \mathrm{complex} \mathrm{is} \mathrm{indispensable} \mathrm{for}$ HCMV entry into both EnCs and EpCs. UL128 protein plays an important role in HCMV infection. It is necessary to make deeper studies to explore the relationship between UL128 gene and HCMV infection.

Acknowledgement. This work was supported by the grants No. 81071337 and No. 81200486 from the National Natural Science Foundation of China, the grant No. Z2110006 from the Natural Science Foundation of Zhejiang Province, and the grant No. Y201017974 from the General Project of Education Department of Zhejiang Province.

\section{References}

Adler B, Scrivano L, Ruzcics Z, Rupp B, Sinzger C, Koszinowski U, J. Gen. Virol. 87, 2451-2460, 2006. http://dx.doi. org/10.1099/vir.0.81921-0

Akter P, Cunningham C, McSharry BP, Dolan A, Addison C, Dargan DJ, Hassan-Walker AF, Emery VC, Griffiths PD, Wilkinson G, Davison AJ, J. Gen. Virol. 84, 1117-1122, 2003. http://dx.doi.org/10.1099/vir.0.18952-0

Avdic S, Cao JZ, Cheung AK, Abendroth A, Slobedman B, J. Virol. 85, 7465-7471, 2011. http://dx.doi.org/10.1128/JVI.00088-11

Baldanti F, Paolucci S, Campanini G, Sarasini A, Percivalle E, Revello MG, Gerna G, Arch. Virol. 151, 1225-1233, 2006. http://dx.doi.org/10.1007/s00705-005-0696-5

Bissinger AL, Sinzger C, Kaiserling E, Jahn G, J. Med. Virol. 67, 200-206, 2002. http://dx.doi.org/10.1002/jmv.2208 
Botto S, Streblow DN, DeFilippis V, White L, Kreklywich CN, Smith PP, Caposio P, Blood. 117, 352-361, 2011. http://dx.doi. org/10.1182/blood-2010-06-291245

Cannon MJ, Schmid DS, Hyde TB, Rev. Med. Virol. 20, 202-213, 2010. http://dx.doi.org/10.1002/rmv.655

Chan G, Nogalski MT, Stevenson EV, Yurochko AD, J. Leukoc. Biol. 92, 743-752, 2012. http://dx.doi.org/10.1189/jlb.0112040

Cheung AK, Abendroth A, Cunningham AL, Slobedman B, Blood 108, 3691-3699, 2006. http://dx.doi.org/10.1182/blood2005-12-026682

Dargan DJ, Douglas E, Cunningham C, Jamieson F, Stanton RJ, Baluchova K, McSharry BP, Tomasec P, Emery VC, Percivalle E, Sarasini A, Gerna G, Wilkinson GW, Davison AJ, J. Gen. Virol. 91, 1535-1546, 2010. http://dx.doi. org/10.1099/vir.0.018994-0

Docke WD, Kiessling C, Worm M, Friedrich M, Pruss A, Weitz M, Prosch S, Kern F, Volk HD, Sterry W, Asadullah K, Br. J. Dermatol. 148, 954-963, 2003. http://dx.doi. org/10.1046/j.1365-2133.2003.05263.x

Dolan A, Cunningham C, Hector RD, Hassan-Walker AF, Lee L, Addison C, Dargan DJ, McGeoch DJ, Gatherer D, Emery VC, Griffiths PD, Sinzger C, McSharry BP, Wilkinson G, Davison AJ, J. Gen. Virol. 85, 1301-1312, 2004. http:// dx.doi.org/10.1099/vir.0.79888-0

Fiorentini S, Luganini A, Dell'Oste V, Lorusso B, Cervi E, Caccuri F, Bonardelli S, Landolfo S, Caruso A, Gribaudo G, J. Gen. Virol. 92, 650-660, 2011. http://dx.doi.org/10.1099/ vir.0.025395-0

Frascaroli G, Varani S, Moepps B, Sinzger C, Landini MP, Mertens T, J. Virol. 80, 7578-7589, 2006. http://dx.doi.org/10.1128/ JVI.02421-05

Gao H, Tao R, Zheng Q, Xu J, Shang S, Arch. Virol. 158, 173-177, 2012.

Gerna G, Sarasini A, Patrone M, Percivalle E, Fiorina L, Campanini G, Gallina A, Baldanti F, Revello MG, J. Gen. Virol. 89, 853-865, 2008. http://dx.doi.org/10.1099/vir.0.83523-0

Grazia RM, Baldanti F, Percivalle E, Sarasini A, De-Giuli L, Genini E, Lilleri D, Labo N, Gerna G, J. Gen. Virol. 82, 1429-1438, 2001.

Hahn G, Revello MG, Patrone M, Percivalle E, Campanini G, Sarasini A, Wagner M, Gallina A, Milanesi G, Koszinowski U, Baldanti F, Gerna G, J. Virol. 78, 10023-10033, 2004. http://dx.doi.org/10.1128/JVI.78.18.10023-10033.2004

Huang MM, Kew VG, Jestice K, Wills MR, Reeves MB, J. Virol. 86, 8507-8515, 2012. http://dx.doi.org/10.1128/JVI.00598-12

Kutza A, MuhlE, Hackstein H, Kirchner A, and Bein G, Clin. Infect. Dis. 26, 1076-1082, 1998. http://dx.doi.org/10.1086/520307

Lira SA, Furtado GC, Immunol. Res. 54, 111-120, 2012. http:// dx.doi.org/10.1007/s12026-012-8313-7

Macagno A, Bernasconi NL, Vanzetta F, Dander E, Sarasini A, Revello MG, Gerna G, Sallusto F, Lanzavecchia A, J. Virol. 84, 10051013, 2010. http://dx.doi.org/10.1128/JVI.01809-09

McCormick AL, Roback L, Livingston-Rosanoff D, St Clair C, J. Virol. 84, 5108-5123, 2010. http://dx.doi.org/10.1128/ JVI.01345-09

Montag C, Wagner JA, Gruska I, Vetter B, Wiebusch L, Hagemeier C, J. Virol. 85, 11409-11421, 2011. http://dx.doi. org/10.1128/JVI.05028-11
Patrone M, Secchi M, Fiorina L, Ierardi M, Milanesi G, Gallina A, J. Virol. 79, 8361-8373, 2005. http://dx.doi.org/10.1128/ JVI.79.13.8361-8373.2005

Patrone M, Secchi M, Bonaparte E, Milanesi G, Gallina A, J. Virol. 81, 11479-11488, 2007. http://dx.doi.org/10.1128/ JVI.00788-07

Penfold ME, Dairaghi DJ, Duke GM, Saederup N, Mocarski ES, Kemble GW, Schall TJ, Proc. Natl. Acad. Sci. USA. 96, 9839-9844, 1999. http://dx.doi.org/10.1073/ pnas. 96.17 .9839

Quirici N, Soligo D, Caneva L, Servida F, Bossolasco P, Deliliers GL, Br. J. Haematol. 115, 186-194, 2001. http://dx.doi. org/10.1046/j.1365-2141.2001.03077.x

Reeves M, Sinclair J, Curr. Top. Microbiol. Immunol. 325, 297-313, 2008. http://dx.doi.org/10.1007/978-3-540$\underline{77349-8 \quad 17}$

Reeves MB, Compton T, J. Virol. 85, 12750-12758, 2011. http:// dx.doi.org/10.1128/JVI.05878-11

Revello MG, Gerna G, Rev. Med. Virol. 20, 136-155, 2010. http:// dx.doi.org/10.1002/rmv.645

Ryckman BJ, Jarvis MA, Drummond DD, Nelson JA, Johnson DC, J. Virol. 80, 710-722, 2006. http://dx.doi.org/10.1128/ JVI.80.2.710-722.2006

Ryckman BJ, Chase MC, Johnson DC, P. Natl. Acad. Sci. USA 105, 14118-14123, 2008a. http://dx.doi.org/10.1073/ pnas.0804365105

Ryckman BJ, Rainish BL, Chase MC, Borton JA, Nelson JA, Jarvis MA, Johnson DC, J. Virol. 82, 60-70, 2008b. http://dx.doi. org/10.1128/JVI.01910-07

Scrivano L, Sinzger C, Nitschko H, Koszinowski UH, Adler B, PLoS. Pathog. 7, e1001256, 2011. http://dx.doi.org/10.1371/ journal.ppat.1001256

Sinzger C, Digel M, Jahn G, Curr. Top. Microbiol. Immunol. 325, 63-83, 2008. http://dx.doi.org/10.1007/978-3-540-77349-8 4

Spear PG, Longnecker R, J. Virol. 77, 10179-10185, 2003. http:// dx.doi.org/10.1128/JVI.77.19.10179-10185.2003

Straschewski S, Patrone M, Walther P, Gallina A, Mertens T, Frascaroli G, J. Virol. 85, 5150-5158, 2011. http://dx.doi. org/10.1128/JVI.02100-10

Sun Z, Ren G, Ma Y, Wang N, Ji Y, Qi Y, Li M, He R, Ruan Q, J. Biosci. 35, 365-370, 2010. http://dx.doi.org/10.1007/ $\underline{\text { s12038-010-0041-3 }}$

Tiffany HL, Lautens LL, Gao JL, Pease J, Locati M, Combadiere C, Modi W, Bonner TI, Murphy PM, J. Exp. Med. 186, 165-170, 1997. http://dx.doi.org/10.1084/jem.186.1.165

Vanarsdall AL, Ryckman BJ, Chase MC, Johnson DC, J. Virol. 82, 11837-11850, 2008. http://dx.doi.org/10.1128/ IVI.01623-08

Vomaske J, Denton M, Kreklywich C, Andoh T, Osborn JM, Chen D, Messaoudi I, Orloff SL, Streblow DN, J. Virol. 86, 1183311844, 2012. http://dx.doi.org/10.1128/JVI.00452-12

Wang D, Shenk T, P. Natl. Acad. Sci. U. S. A. 102, 18153-18158, 2005. http://dx.doi.org/10.1073/pnas.0509201102

Wang X, Huang DY, Huong SM, Huang ES, Nat. Med. 11, 515-521, 2005. http://dx.doi.org/10.1038/nm1236

Zheng Q, Tao R, Gao HH, Xu J, Shang SQ, Zhao N, Viral. Immunol. 25, 98-105, 2012. http://dx.doi.org/10.1089/ vim.2011.0064 